\title{
ANALISIS VARIABEL YANG MEMENGARUHI PERTUMBUHAN DAN PENINGKATAN DAYA SAING INDUSTRI AMPLANG SAMARINDA
}

\author{
MURIANI EMELDA ISHARYANI, MUHAMMAD YUDA ANANTA DAN DEASY KARTIKA RAHAYU K \\ Program Studi Teknik Industri, Fakultas Teknik Universitas Mulawarman, Samarinda \\ Jl. Sambaliung No. 9 Kampus Gunung Kelua, Samarinda 75119 \\ Surel: murianiemelda@gmail.com
}

\begin{abstract}
ABSTRAK
Beberapa masalah yang terjadi pada industri amplang Samarinda menuntut perlunya diketahui indikator dan faktor yang memengaruhi pertumbuhan dan peningkatan daya saing industri amplang Samarinda. Identifikasi dan analisis dilakukan dengan metode Structural Equation Modelling (SEM) terhadap indikator dan faktor dari model Diamond Porter. Hasil dari penelitian ini menunjukkan bahwa semua indikator yang menyusun dan membentuk setiap faktor dari model Diamond Porter terbukti mempunyai hubungan yang positif dan signifikan terhadap masing-masing faktornya. Setiap indikator terbukti berpengaruh secara positif dan signifikan terhadap pertumbuhan dan peningkatan daya saing industri amplang Samarinda. Faktor-faktor dari model Diamond Porter secara positif dan signifikan terbukti berpengaruh terhadap pertumbuhan dan peningkatan daya saing industri amplang Samarinda. Dari faktor-faktor maupun indikator-indikator yang berpengaruh tersebut, dapat diidentifikasi bahwa faktor kondisi dan sumber daya serta indikator ketersediaan sumber daya modal merupakan faktor dan indikator yang paling berpengaruh terhadap pertumbuhan dan peningkatan daya saing industri amplang Samarinda.
\end{abstract}

Kata kunci: industri amplang, pertumbuhan dan peningkatan daya saing, model diamond porter, SEM

\begin{abstract}
Several problems occurred in amplang industry of Samarinda insists on discovering indicators and factors affecting the growth and improvement of amplang industry's competitiveness of Samarinda. Identification and analysis are done by using Structural Equation Modelling (SEM) method toward indicators and factors of Diamond Porter model. The results of this research indicates that all indicators that compose and build each factor of Diamond Porter model literally have a positive and significant correlation to each factor. Each indicator evidently influences positively and significantly on the growth and improvement of amplang industry's competitiveness of Samarinda. Moreover, factors of Diamond Porter model positively and significantly evidently influence to the growth and improvement of amplang industry's competitiveness of Samarinda. Based on the influential factors and indicators, it can be identified that condition \& resource and capital resource availability are the most influential factor and indicator on the growth and improvement of amplang industry's competitiveness of Samarinda.
\end{abstract}

Key words: amplang industry, growth and improvement of competitiveness, diamond porter model, SEM

\section{PENDAHULUAN}

Samarinda sebagai kota jasa dan perdagangan memiliki peningkatan perindustrian yang cukup pesat, terutama kelompok Industri Kecil dan
Menengah (IKM). Sampai tahun 2009, jumlah IKM di Kota Samarinda telah mencapai 1.033 unit, meningkat 6\% dari tahun 2008. Selain berdampak positif pada investasi, IKM juga

* Penulis korespondensi 
memberikan dampak yang sama pada penyerapan jumlah tenaga kerja, di mana hingga tahun 2009, jumlah tenaga kerja yang terserap mencapai 8.876 jiwa dengan rata-rata penyerapan delapan tenaga kerja per IKM (Bappeda, 2013). Salah satu IKM yang cukup berkembang pesat di Samarinda adalah industri makanan amplang yaitu makanan ringan yang terbuat dari bahan baku ikan berbentuk bulat dan berwarna putih kecoklat-coklatan. Saat ini telah banyak IKM yang didirikan oleh masyarakat dan bergerak dalam industri produksi ataupun penjualan produk amplang. Dari wawancara dengan beberapa para pengusaha amplang diketahui bahwa terdapat beberapa permasalahan yang terjadi pada IKM produk amplang ini khususnya terkait dengan problematika daya saing, seperti biaya produksi yang terus meningkat sehingga produk yang ditawarkan harganya tinggi, kapasitas penjualan masih terbatas, masalah kaderisasi IKM, segala aktivitas penjualan dan promosi yang masih dipegang sendiri oleh pemilik usaha, serta adanya permasalahan ketersediaan bahan baku utama yang semakin lama semakin sulit dicari. Dengan adanya permasalahan-permasalahan tersebut tentu dapat mengganggu pertumbuhan dan peningkatan daya saing industri amplang di Samarinda.

Penelitian ini dilakukan untuk mengetahui indikator-indikator dan faktor-faktor yang memengaruhi pertumbuhan dan peningkatan daya saing industri amplang di Samarinda yang diharapkan dapat memberikan suatu rekomendasi yang dapat mengoptimalkan pertumbuhan dan meningkatkan daya saing industri amplang di Samarinda. Sebagai acuan, digunakan model Diamond yang dikembangkan oleh Michael Porter pada tahun 1990. Metode Structural Equation Modelling (SEM) digunakan untuk mengidentifikasi dan menganalisis pengaruh faktor beserta indikator dari model Diamond Porter terhadap pertumbuhan dan peningkatan daya saing industri amplang di Kota Samarinda.

Acuan dan metode yang serupa telah dilakukan oleh Susanty dkk. (2013) yang menitikberatkan penelitiannya pada faktor-faktor yang memengaruhi pertumbuhan klaster batik Pekalongan dan Handayani dkk. (2012) yang lebih menitikberatkan pada peningkatan daya saing klaster mebel di kabupaten Jepara. Penelitian ini akan menganalisis hubungan antar indikator dan faktor terhadap pertumbuhan dan daya saing industri sekaligus tanpa melihat klaster industri yang memang belum dibentuk oleh pemerintah daerah Samarinda. Pertumbuhan yang dimaksud dilihat dari pertumbuhan produksi, pertumbuhan penjualan, pertumbuhan pendapatan dan pertumbuhan laba (Shanmugam dan Bhaduri, 2002) yang telah tercakup dalam faktor dari model Diamond Porter dan diuraikan lebih lanjut dalam bentuk indikator penyusun faktor.

\section{METODE}

Menurut Porter (1990) bahwa konsep daya saing yang dapat diterapkan pada level nasional tidak lain adalah produktivitas yang didefinisikan sebagai nilai output yang dihasilkan untuk setiap input yang digunakan. Terdapat empat faktor utama yang menentukan daya saing industri di suatu wilayah, yaitu kondisi sumber daya; kondisi permintaan; kondisi industri terkait dan industri pendukung; serta kondisi struktur, persaingan dan strategi perusahaan. Keempat atribut tersebut didukung oleh peranan pemerintah dan peranan kesempatan dalam meningkatkan keunggulan daya saing industri wilayah yang secara bersamasama membentuk suatu sistem. Selanjutnya konsep ini dikenal dengan model Diamond Porter. Sedangkan pertumbuhan industri dapat dinilai dari pertumbuhan produksi, pertumbuhan penjualan, pertumbuhan pendapatan dan pertumbuhan laba. Berdasarkan model Diamond Porter dan indikator pertumbuhan usaha, model konseptual dari penelitian ini dapat digambarkan sebagaimana terlihat pada Gambar 1.

Faktor-faktor dari model konseptual digunakan untuk mengukur pertumbuhan dan daya saing industri (TDS). Faktor kondisi sumber daya (KFS) dibangun oleh lima indikator, yaitu ketersediaan bahan baku dan SDA (KFS1), ketersediaan tenaga kerja handal (KFS2), 
ketersediaan sumber daya IPTEK (KFS3), ketersediaan sumber daya modal (KFS4), dan ketersediaan sarana dan prasarana pendukung (KFS5). Faktor kondisi permintaan (KP) diukur dengan tiga indikator yaitu karakteristik selera permintaan konsumen yang tinggi dan bermacam-macam (KP1), jumlah dan tingkat permintaan konsumen (KP2), dan konsumen lokal yang tinggal di luar negeri (KP3). Faktor industri terkait dan industri pendukung (ITIP) diukur dengan 2 indikator yaitu kondisi baikburuknya industri pendukung (ITIP1) serta kondisi baik-buruknya industri terkait (ITIP2). Faktor struktur pasar, persaingan dan strategi perusahaan (SPSP) diukur dengan 3 indikator yaitu tipe, jenis, dan sistem pasar penjualan (SPSP1), persaingan perusahaan dalam membuat produk yang kreatif, inovatif, dan variatif (SPSP2), dan strategi perusahaan dalam mengembangkan usaha dan menarik minat konsumen (SPSP3). Faktor peran pemerintah (PP) diukur dengan 2 indikator yaitu kebijakan yang dibuat pemerintah daerah (PP1) serta bantuan teknis dan perhatian yang diberikan pemerintah daerah (PP2). Sedangkan Faktor kesempatan (KS) diukur dengan 2 indikator yaitu kondisi perekonomian dan perpolitikan di daerah (KS1) serta perkembangan alat teknologi (KS2).

Berdasarkan model konseptual tersebut, maka dapat disusun hipotesis penelitian sebagai berikut:

Hipotesis 1 : faktor kondisi sumber daya memengaruhi pertumbuhan dan peningkatan daya saing industri amplang.

Hipotesis 2 : kondisi permintaan memengaruhi pertumbuhan dan peningkatan daya saing industri amplang.

Hipotesis 3 : industri terkait dan industri pendukung memengaruhi pertumbuhan dan peningkatan daya saing industri amplang.

Hipotesis 4 : struktur pasar, persaingan dan strategi perusahaan memengaruhi pertumbuhan dan peningkatan daya saing industri amplang.

Hipotesis 5 : peran pemerintah memengaruhi pertumbuhan dan peningkatan daya saing industri amplang.

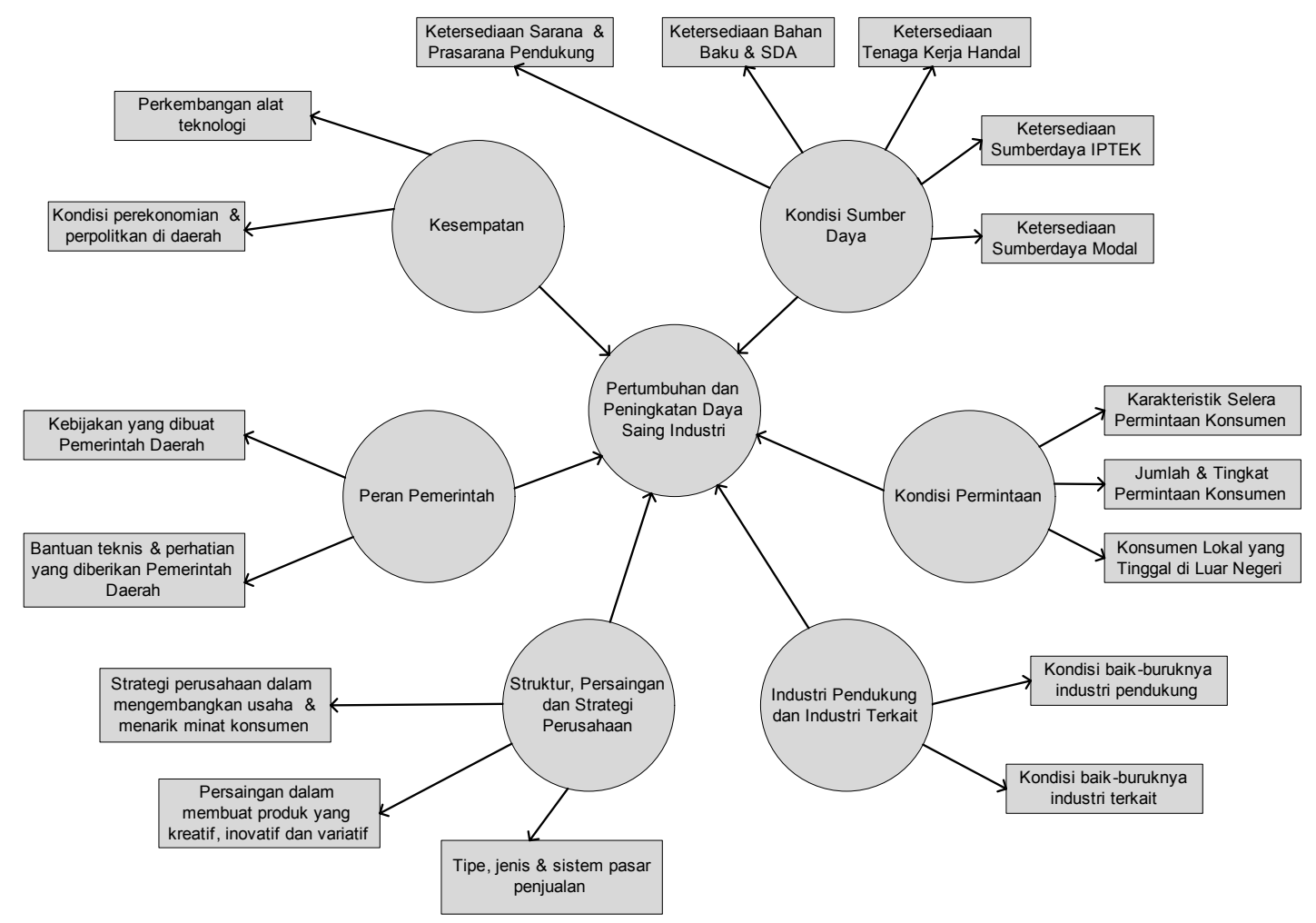

Gambar 1. Model Konseptual Penelitian 
Hipotesis 6 : kesempatan memengaruhi pertumbuhan dan peningkatan daya saing industri amplang.

Pengumpulan data primer dilakukan dengan menyebarkan kuesioner kepada para pemilik usaha amplang untuk selanjutnya diolah dan dianalisis dengan menggunakan Metode SEM melalui penggunaan software Smart PLS 2.0. Structural Equation Modeling (SEM) adalah suatu teknik statistik yang mampu menganalisis pola hubungan antara konstrak laten dan indikatornya, konstrak laten yang satu dengan yang lainnya, serta pengukuran secara langsung. SEM merupakan keluarga statistik multivariate dependent. SEM memungkinkan dilakukannya analisis di antara beberapa variabel dependent dan independent secara langsung (Hair et al., 2006). Menurut Ghozali dan Fuad (2006) dan Ghozali (2011), model SEM berbasis component atau variance - dengan PLS orientasi analisis bergeser dari menguji model kausalitas/teori ke component based predictive model. Ghozali (2011) menyatakan bahwa Partial Least Square (PLS) merupakan metode analisis yang kuat oleh karena tidak didasarkan banyak asumsi. Data tidak harus berdistribusi normal multivariate (indikator dengan skala kategori, ordinal, interval, sampai ratio dapat digunakan pada model yang sama) dan sampel tidak harus besar.

Dalam metode SEM, terdapat tiga istilah penting yang digunakan dalam penelitian ini, yaitu variabel manifest yang berlaku untuk 17 indikator yang menyusun 6 faktor model Diamond Porter, first order construct yang berlaku untuk 6 faktor dari model Diamond Porter dan second order construct yang berlaku untuk dimensi atau konstruk pertumbuhan dan peningkatan daya saing industri amplang Kota Samarinda yang merupakan sasaran atau objek utama dalam penelitian ini. First order construct dan second order construct disebut juga variabel laten.

Dalam menganalisis model ini, pendekatan yang digunakan adalah pendekatan repeat indicator approach, di mana indikator digunakan berulang sebagai indikator pada second order construct dan juga sebagai indikator pada first order construct. Model analisis jalur semua variabel laten dalam PLS terdiri dari tiga set hubungan: (1) inner model, yang menspesifikasi hubungan antar variabel laten (structural model), (2) outer model, yang menspesifikasi hubungan antar variabel laten dengan indikator atau variabel manifestnya (measurement model), (3) weight relation dalam mana nilai kasus dari variabel laten dapat diestimasi (Ghozali, 2011). Besarnya tiga macam hubungan tersebut, yaitu antara indikator dengan first order construct, indikator dengan second order construct, maupun antara first order construct dengan second order construct, dianalisis dengan melihat nilai dari koefisien jalur.

\section{HASIL DAN PEMBAHASAN}

Analisis pengaruh indikator terhadap faktor dalam hal ini bisa disebut dengan analisis outer model. Pada dasarnya, analisis outer model merupakan pengujian validitas dan reliabilitas terhadap variabel-variabel yang diukur. Terdapat tiga kriteria untuk menilai outer model yaitu convergent validity, discriminant validity, dan composite reliability.

\section{Convergent Validity}

Convergent validity bertujuan untuk memvalidasi apakah semua item-item yang menjadi indikator dari suatu konstruk mempunyai hubungan yang signifikan dengan konstruknya, yang dinilai dari besarnya nilai faktor loading masing-masing indikator terhadap konstruknya. Menurut Ghozali (2011), nilai loading factor $>0,7$ sangat direkomendasikan namun nilai antara 0,5-0,6 masih dapat diterima sepanjang model masih dalam tahap pengembangan. Adapun nilai faktor loading antara indikator dengan first order construct selengkapnya dapat dilihat pada Tabel 1.

Terlihat pada Tabel 1 bahwa semua indikator memiliki nilai faktor loading $>0,7$ maka dapat disimpulkan bahwa indikator pada faktor memiliki hubungan korelasi yang positif dan signifikan dengan konstruknya serta memiliki validitas konvergen yang baik yang artinya 
semua indikator-indikator mampu mengukur atau menjadi alat ukur yang tepat dan cermat terhadap masing-masing faktornya (valid).

2. Discriminant Validity

Discriminant validity berguna untuk menilai apakah konstruk memiliki validitas diskriminan yang memadai yaitu dengan cara membandingkan korelasi antara indikator dengan konstruknya harus lebih tinggi dibandingkan korelasi dengan konstruk lainnya. Nilai discriminant validity dapat dilihat pada nilai cross loading factor-nya sebagaimana terlihat pada Tabel 2 .

Pada Tabel 2 terlihat semua nilai cross loading indikator ke konstruk yang dituju lebih tinggi dibandingkan ke konstruk yang lain, hal ini membuktikan bahwa semua indikator tersebut memiliki discriminant validity yang baik yang artinya semua indikator telah tepat, cermat, dan dapat mengukur, menyusun, maupun membentuk setiap faktor yang ditujunya masing-masing dibanding dengan faktor lain yang bukan utama untuk dituju. Selain dengan melihat nilai dari cross loading, discriminant validity juga dapat dilihat dari nilai Average Variance Extracted (AVE). Menurut Ghazali (2011), batasan nilai AVE yang baik yaitu sebesar > 0,5. Hasil nilai AVE selengkapnya dapat dilihat pada Tabel 3, di mana semua konstruk memiliki nilai AVE > 0,5 yang menunjukkan bahwa setiap faktor telah mampu memprediksi faktor loading indikatorindikator yang berkorelasi dengannya lebih baik dibanding faktor lainnya.

3. Composite Reliability

Composite Reliability digunakan untuk mengukur internal consistency dari sebuah blok konstruk. Menurut Ghozali (2011), sebuah konstruk yang memiliki nilai composite reliability $>0,6$ dapat dikatakan indikatorindikator yang menyusun konstruk tersebut telah handal dan konsisten dalam mengukur konstruk yang dituju (reliabel). Nilai composite reliability dapat dilihat pada Tabel 4 .

Semua konstruk memiliki nilai composite reliability di atas $>0,6$; hal ini dapat diartikan bahwa semua indikator yang menyusun atau mengukur masing-masing faktor yang ditujunya tersebut telah handal dan konsisten dalam mengukur (reliabel). Selain dengan cara diatas, internal consistency konstruk dapat juga diuji dengan mengetahui nilai alpha cronbach's. Menurut Ghozali (2011), nilai alpha cronbach's $>0,7$ berarti dapat diterima. Sedangkan menurut Rozandy (2013), indikator dapat dikatakan reliabel

Tabel 1. Nilai Faktor Loading antara Indikator dengan First Order Construct

\begin{tabular}{|c|c|c|c|c|c|c|}
\hline & ITIP & KFS & KP & KS & PP & SPSP \\
\hline ITIP1 & 0,8811 & & & & & \\
\hline ITIP2 & 0,9003 & & & & & \\
\hline KFS1 & & 0,8850 & & & & \\
\hline KFS2 & & 0,8948 & & & & \\
\hline KFS3 & & 0,9276 & & & & \\
\hline KFS4 & & 0,9328 & & & & \\
\hline KFS5 & & 0,8617 & & & & \\
\hline KP1 & & & 0,8900 & & & \\
\hline KP2 & & & 0,9378 & & & \\
\hline KP3 & & & 0,9000 & & & \\
\hline KS1 & & & & 0,9179 & & \\
\hline KS2 & & & & 0,9211 & & \\
\hline PP1 & & & & & 0,9395 & \\
\hline PP2 & & & & & 0,9479 & \\
\hline SPSP1 & & & & & & 0,8473 \\
\hline SPSP2 & & & & & & 0,8942 \\
\hline SPSP3 & & & & & & 0,8534 \\
\hline
\end{tabular}


Tabel 2. Nilai Cross Loading antara Indikator dengan Konstruk-konstruk

\begin{tabular}{lllllll}
\hline & ITIP & KFS & KP & KS & PP & SPSP \\
\hline ITIP1 & 0,8811 & 0,6785 & 0,7112 & 0,6143 & 0,6775 & 0,6863 \\
ITIP2 & 0,9003 & 0,7338 & 0,7932 & 0,7603 & 0,7096 & 0,7204 \\
KFS1 & 0,6676 & 0,8850 & 0,6628 & 0,6978 & 0,6639 & 0,602 \\
KFS2 & 0,6104 & 0,8948 & 0,6306 & 0,6513 & 0,6725 & 0,5468 \\
KFS3 & 0,7424 & 0,9276 & 0,7977 & 0,7146 & 0,7544 & 0,6569 \\
KFS4 & 0,7482 & 0,9328 & 0,8572 & 0,7818 & 0,7797 & 0,6492 \\
KFS5 & 0,7929 & 0,8617 & 0,8011 & 0,6686 & 0,6835 & 0,698 \\
KP1 & 0,7864 & 0,7518 & 0,8900 & 0,5443 & 0,6235 & 0,5316 \\
KP2 & 0,767 & 0,8274 & 0,9378 & 0,7416 & 0,8241 & 0,6679 \\
KP3 & 0,7585 & 0,7024 & 0,9000 & 0,6957 & 0,8103 & 0,6669 \\
KS1 & 0,7582 & 0,6458 & 0,6195 & 0,9179 & 0,7582 & 0,8267 \\
KS2 & 0,6673 & 0,791 & 0,7225 & 0,9211 & 0,7471 & 0,5862 \\
PP1 & 0,7411 & 0,6915 & 0,7565 & 0,7228 & 0,9395 & 0,7561 \\
PP2 & 0,73 & 0,7983 & 0,8111 & 0,8188 & 0,9479 & 0,7804 \\
SPSP1 & 0,6257 & 0,6374 & 0,5889 & 0,6121 & 0,6682 & 0,8473 \\
SPSP2 & 0,7306 & 0,6349 & 0,5569 & 0,7016 & 0,7087 & 0,8942 \\
SPSP3 & 0,6928 & 0,55 & 0,6378 & 0,6758 & 0,7369 & 0,8534 \\
\hline
\end{tabular}

Tabel 3. Nilai AVE dari Setiap Konstruk

\begin{tabular}{lc}
\hline \multicolumn{1}{c}{ Konstruk } & AVE \\
\hline ITIP & 0,7934 \\
KFS & 0,8114 \\
KP & 0,8273 \\
KS & 0,8454 \\
PP & 0,8905 \\
SPSP & 0,7486 \\
Tumbuh dan Daya Saing & 0,6691 \\
\hline
\end{tabular}

Tabel 4. Nilai Composite Reliability dari Setiap Konstruk

\begin{tabular}{lc}
\hline \multicolumn{1}{c}{ Konstruk } & Composite Reliability \\
\hline ITIP & 0,8848 \\
KFS & 0,9555 \\
KP & 0,9349 \\
KS & 0,9162 \\
PP & 0,9421 \\
SPSP & 0,8993 \\
Tumbuh dan Daya Saing & 0,9716 \\
\hline
\end{tabular}

bila memiliki alpha cronbach's sebesar 0,6 atau lebih. Terlihat pada Tabel 5, nilai alpha cronbach's semua konstruk > 0,7 yang berarti faktor-faktor tersebut memiliki internal consistency yang dapat diterima.
Tabel 5. Nilai alpha cronbach's dari Setiap Konstruk

\begin{tabular}{lc}
\hline \multicolumn{1}{c}{ Konstruk } & alpha cronbach's \\
\hline ITIP & 0,7401 \\
KFS & 0,9417 \\
KP & 0,8954 \\
KS & 0,8172 \\
PP & 0,8773 \\
SPSP & 0,8317 \\
Tumbuh dan Daya Saing & 0,9687 \\
\hline
\end{tabular}

Berdasarkan hasil analisis outer model yang telah dilakukan melalui tiga tahapan kriteria, maka dapat disimpulkan bahwa terdapat hubungan atau korelasi yang positif dan signifikan antara indikator dengan faktornya, hal ini dapat dilihat pada convergent validitynya. Selain itu, masing-masing indikator juga telah tepat menyusun masing-masing faktornya (faktor memiliki indikator yang benar sebagai penyusunnya), hal ini dapat dilihat pada discriminant validity-nya. Masing-masing indikator telah handal dan konsisten dalam mengukur dan menyusun faktornya, hal ini dapat dilihat dari composite reliability. Dengan demikian hal ini membuktikan secara umum bahwa semua indikator yang dibuat mempunyai 
pengaruh terhadap masing-masing faktor dalam model Diamond Porter.

Analisis outer model selanjutnya adalah analisis pengaruh indikator terhadap pertumbuhan dan peningkatan daya saing industri amplang Kota Samarinda (second order construct), di mana hanya melibatkan convergent validity dan composite reliability, karena tujuan dari discriminant validity adalah untuk melihat apakah sekelompok indikator yang termasuk dalam suatu konstruk dapat dibedakan jelas dari konstruk lainnya, sementara pada dasarnya indikator-indikator yang ada bukanlah penyusun utama dari konstruk pertumbuhan dan peningkatan daya saing industri amplang Kota Samarinda yang bersifat sebagai second order construct (indikator yang ada merupakan penyusun dari first order construct).

Pada Tabel 6 terlihat nilai faktor loading semua indikator terhadap second order construct lebih besar dari 0,7 yang menandakan bahwa indikator terhadap second order construct (pertumbuhan dan peningkatan daya saing industri amplang) memiliki hubungan korelasi yang positif dan signifikan dan memiliki validitas konvergen yang baik yaitu semua indikatorindikator penyusun konstruk pertumbuhan dan peningkatan daya saing industri amplang Kota Samarinda mampu mengukur atau menjadi alat ukur yang tepat dan cermat (valid) terhadap pertumbuhan dan peningkatan daya saing industri amplang Kota Samarinda. Sedangkan internal consistency terlihat dari nilai composite reliability konstruk pertumbuhan dan daya saing industri amplang sebesar 0,9716 dan alpha cronbach's konstruk pertumbuhan dan daya saing industri amplang sebesar 0,9687 yang lebih besar dari 0,6 yang berarti semua indikator dari masingmasing faktor yang menyusun atau mengukur konstruk pertumbuhan dan peningkatan daya saing industri amplang Kota Samarinda tersebut telah handal dan konsisten dalam mengukur (reliable).

Analisis inner model adalah mengevaluasi hubungan antara konstruk seperti yang telah dihipotesiskan dalam penelitian ini yaitu
Tabel 6. Nilai Faktor Loading antara Indikator dengan Second Order Construct

\begin{tabular}{lc}
\hline Indikator & Tumbuh dan Daya Saing \\
\hline ITIP1 & 0,7726 \\
ITIP2 & 0,8393 \\
KFS1 & 0,7994 \\
KFS2 & 0,7749 \\
KFS3 & 0,8744 \\
KFS4 & 0,8999 \\
KFS5 & 0,8504 \\
KP1 & 0,7777 \\
KP2 & 0,8876 \\
KP3 & 0,8292 \\
KS1 & 0,8030 \\
KS2 & 0,8186 \\
PP1 & 0,8319 \\
PP2 & 0,8948 \\
SPSP1 & 0,7279 \\
SPSP2 & 0,7594 \\
SPSP3 & 0,7363 \\
\hline
\end{tabular}

bagaimana hubungan pengaruh antara first order construct (faktor-faktor) terhadap second order construct (pertumbuhan dan peningkatan daya saing industri amplang Kota Samarinda). Pengujian hubungan pengaruh antar konstruk dapat dilihat dari nilai t-statistik yang dilakukan pada taraf signifikansi 5\% dengan $\mathrm{db}=30$, di mana jika nilai t-statistik $>1,96$ maka kesimpulan pengambilan keputusan dinyatakan bahwa terdapat pengaruh yang positif dan signifikan antara kedua konstruk tersebut. Hasil pengujian hubungan pengaruh tersebut adalah sebagai berikut: Hipotesis 1 diterima, artinya konstruk faktor kondisi sumber daya terbukti secara statistik memengaruhi pertumbuhan dan peningkatan daya saing industri amplang Samarinda dikarenakan nilai t-statistik pada hubungan ini adalah 7,9654 berada dalam area penerimaan. Hipotesis 2 diterima, artinya konstruk kondisi permintaan terbukti secara statistik memengaruhi pertumbuhan dan peningkatan daya saing industri amplang Samarinda dengan nilai t-statistik sebesar 9,2315 yang berada dalam area penerimaan. Hipotesis 3 diterima, karena berada dalam area penerimaan dengan t-statistik sebesar 9,2299 yang berarti konstruk industri terkait dan pendukung terbukti 
secara statistik memengaruhi pertumbuhan dan peningkatan daya saing industri amplang Samarinda. Hipotesis 4 diterima dengan tstatistik sebesar 8,8554 berada dalam area penerimaan, yang berarti konstruk struktur pasar, persaingan dan strategi perusahaan memengaruhi pertumbuhan dan peningkatan daya saing industri amplang Samarinda. Hipotesis 5 diterima dengan t-statistik sebesar 13,0119 berada dalam area penerimaan yang berarti peran pemerintah memengaruhi pertumbuhan dan peningkatan daya saing industri amplang Samarinda. Hipotesis 6 diterima dengan t-statistik sebesar 8,1191 berada dalam area penerimaan yang berarti konstruk kesempatan terbukti secara statistik memengaruhi pertumbuhan dan peningkatan daya saing industri amplang Samarinda.

Nilai original sample $(\mathrm{O})$ yang juga merupakan nilai koefisien jalur (path coefficient) sebagaimana terlihat pada Gambar 2, menunjukkan besarnya hubungan pengaruh konstruk, yang dapat menunjukkan faktor dan indikator yang paling berpengaruh terhadap pertumbuhan dan peningkatan daya saing industri amplang Kota Samarinda. Hal ini dapat dilihat dari faktor dan indikator yang memiliki nilai original sample atau nilai koefisien jalur yang paling besar di antara semua faktor dan indikator yang terbukti berpengaruh, yang dapat dilihat pada Gambar 2, di mana konstruk kondisi faktor sumber daya (KFS) memiliki nilai koefisien jalur terbesar dengan nilai sebesar 0,333. Pada indikator ketersediaan sumber daya modal (KFS4), merupakan indikator dengan nilai koefisien jalur terbesar dengan nilai sebesar 0,9 .

Secara umum terlepas dari kondisi faktor sumber daya dan ketersediaan sumber daya modal merupakan faktor dan indikator yang paling berpengaruh berdasarkan dari hasil penelitian ini, namun seluruh faktor dan indikator yang ada harus tetap dipertimbangkan bersama oleh seluruh lapisan stakeholders terkait karena semua faktor dan indikator terbukti secara positif dan signifikan berpengaruh terhadap pertumbuhan dan peningkatan daya saing industri amplang Kota Samarinda.

\section{SIMPULAN}

Berdasarkan analisis outer model terdapat pengaruh yang positif dan signifikan dari setiap indikator terhadap faktor-faktor dari model

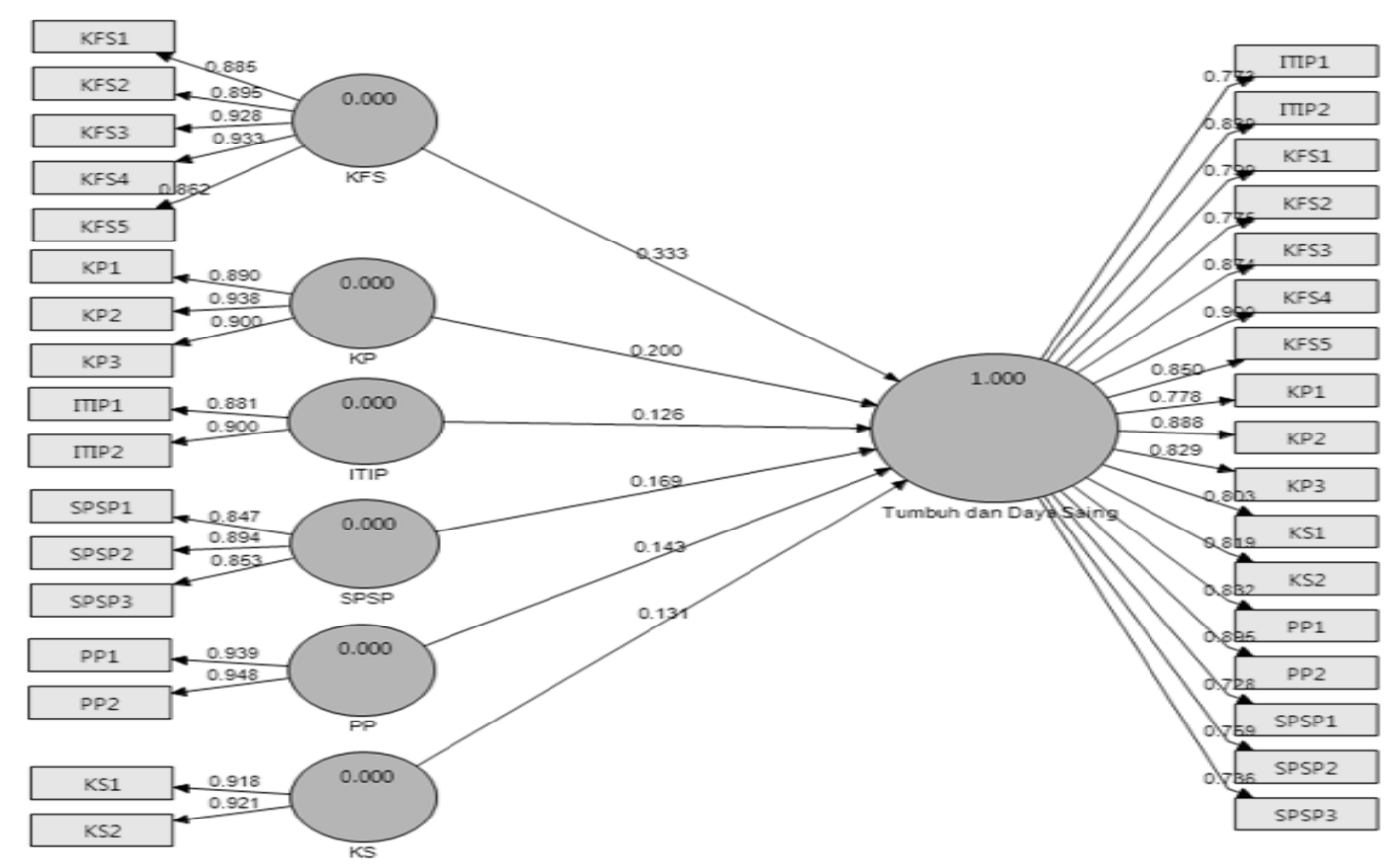

Gambar 2. Besaran Nilai Koefisien Jalur Masing-masing Faktor dan Indikator 
Diamond Porter. Semua indikator yang berjumlah tujuh belas indikator terbukti berpengaruh secara positif dan signifikan terhadap pertumbuhan dan peningkatan daya saing industri amplang Kota Samarinda. Berdasarkan analisis inner model, faktor-faktor dari model Diamond Porter yang memengaruhi pertumbuhan dan peningkatan daya saing industri amplang Kota Samarinda secara positif dan signifikan adalah faktor kondisi, faktor sumber daya, faktor kondisi permintaan, faktor industri pendukung dan industri terkait, faktor struktur pasar, persaingan, dan strategi perusahaan, faktor peran pemerintah, serta faktor kesempatan. Menurut para pengusaha penjualan amplang di Kota Samarinda, faktor dan indikator yang paling berpengaruh terhadap pertumbuhan dan peningkatan daya saing industri amplang Kota Samarinda adalah faktor kondisi sumber daya dan indikator ketersediaan sumber daya modal. Hal ini dapat menjadi suatu pertimbangan bersama oleh seluruh lapisan stakeholders bahwa ketersediaan sumber daya terutama modal telah menjadi dasar bagi pengembangan industri dan mutlak menjadi hal yang paling utama harus tersedia dalam rangka menumbuhkan dan meningkatkan daya saing industri amplang Kota Samarinda. Selain itu, ketersediaan modal yang cukup akan menjadi motivasi bagi para pengusaha amplang untuk mengembangkan usaha amplangnya sehingga dapat bersaing untuk mempromosikan dan menjual produk amplang di Kota Samarinda.

\section{DAFTAR PUSTAKA}

Bappeda Samarinda, http://bappeda.samarindakota. go.id/profil_05.php, diakses tanggal 20-10-2013 pukul 13.34 WITA.

Ghozali, I. dan Fuad, 2006. Structural Equation Modeling, Teori Konsep dan Aplikasi, Semarang: Badan Penerbit Universitas Diponegoro.

Ghozali, I., 2011. Structural Equation Modelling: Metode Alternatif dengan Partial Least Square, Semarang: Badan Penerbit Universitas Diponegoro.

Hair Joseph F.JR, Anderson Rolp E., Tatham Ronald L., Black C. William, 2006. Multivariate Data Analysis, $6^{\text {th }}$ Edition, Pearson Education Inc.

Handayani, N.U., Santoso, H., dan Pratama, A.I.., 2012. Faktor-Faktor yang Mempengaruhi Peningkatan Daya Saing Klaster Mebel di Kabupaten Jepara, Jurnal Teknik Industri, 13 (1), 22-30.

Porter, M., 1990. The Competitive Advantage of Nations, New York: Free Press.

Rozandy, R.A., Santoso, I., Putri, S.A., 2013. Analisis Variabel-Variabel yang Mempengaruhi Tingkat Adopsi Teknologi dengan Menggunakan Partial Least Square (Studi Kasus: Sentra Industri Tahu Desa Sendang Kec. Banyakan Kediri. Jurnal Industria, 1 (3), 147-158.

Shanmugam, K.R., and Bhaduri, S.N., 2002. Size, Age and Firm Growth in the Indian Manufacturing Sector, Applied Economics Letters.

Susanty, A., Handayani, N.U., dan Jati, P.A., 2013. Analisis Faktor-Faktor yang Mempengaruhi Pertumbuhan Klaster Batik Pekalongan (Studi Kasus Pada Klaster Batik Kauman, Pesindon dan Jenggot), J@ti Undip, VIII (1).

Susilo, S., 2007. Pertumbuhan Usaha Industri KecilMenengah (IKM) dan Faktor-Faktor yang Memengaruhinya. Eksekutif: Jurnal Nasional Manajemen Bisnis. Sekolah Tinggi Ilmu Ekonomi IBMT, 4 (2), 306-313. 